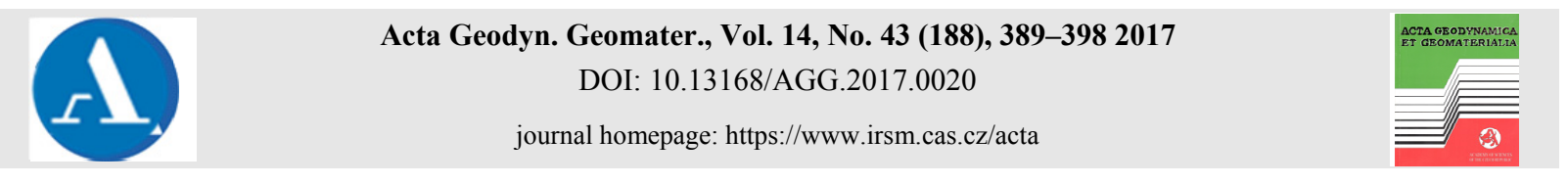

ORIGINAL PAPER

\title{
FINITE ELEMENT MODELING OF TECTONIC STRESS FIELD OF IRAN BASED ON GEODETIC AND SEISMIC DATA
}

\author{
Behzad ZAMANI G. ${ }^{1,2,3)}$ \\ 1) Department of Earth Sciences, Faculty of Natural Sciences, University of Tabriz, 29 Bahman Blvd., Tabriz, Iran. \\ ${ }^{2)}$ Earthquakes Precursors Observatory, Central Lab., University of Tabriz, 29 Bahman Blv., Tabriz, Iran. \\ 3) Abyab Zamin co., No. 55, Atlas Au., Airport Blvd., Tabriz, Iran. \\ *Corresponding author's e-mail: b.zamani@tabrizu.ac.ir
}

\begin{tabular}{l} 
ARTICLE INFO \\
\hline Article history: \\
Received 28 November 2016 \\
Accepted 4 August 2017 \\
Available online 7 November 2017 \\
\hline
\end{tabular}

\section{Keywords:}

Tectonic stress field

Modeling

Finite element

Iran

\begin{abstract}
In this paper, the tectonic stress field of Iran studied by a two-dimensional elastic finite element model (FEM) using inverse modeling technique. Using the named method, the relative magnitude of the tectonic forces and the regional parameters of the major blocks estimated. Geodetic and stress analysis results used for evaluating and validating the results of the developed inverse model. This developed model allows estimating the effect of different parameters of the stress pattern. The results denote that the direction of convergence plays an important role in distribution of the stress pattern, and the shape of the plate boundary is the main factor in controlling the shape of the distribution of the maximum compressional stress. The results also show that the magnitude of the maximum principal stress axes $(\delta 1)$ reduce from the west and southwest to the north and northeast of Iran. The maximum stress magnitude is dominantly in the NW-Zagros, Azarbaijan, Qatar- Kazeron, Kope-Dagh, Zabol block and Lut block, while western part of Iran shows a thrusting mode stress state.
\end{abstract}

\section{INTRODUCTION}

The tectonic stress field pattern of the Iranian plate can be modeled by the finite element method (FEM) using the forces and stress acting on it. For this purpose, the stress inversion results and geodetic data are used in inverse modeling method of FEM. Major sources of stress perturbation expected in the brittle crust, are documented by the local studies of earthquakes in Iran (Zamani et al., 2008; Zamani, 2011; Zamani and Masson; 2014). Zamani (2009) carried out stress inversion analysis of double couple focal mechanisms data within a set of up to 1200 earthquakes in Iran. These results, together with geodetic and stress magnitude data used for modeling the stress in crust. In this study, the relationships between the stress distribution and convergent kinematics in Iran explained.

\section{TECTONIC SETTINGS}

Iran is located within the convergence domain that the geodynamics of the region is dominated by the convergence between the Arabian and Eurasian plates (Jackson and Mckenzie, 1984, 1988). The Arabian-Eurasian convergence of the Hormoz Strait is trending north to NNE.

The historical (Ambraseys and Melville, 1982) and instrumental seismicity (Engdahl et al., 1998) in Iran suggests an intracontinental deformation concentrated in several mountain belts surrounding relatively aseismic blocks (central Iran, Lut and South Caspian blocks, (Vernant et al., 2004)).

The northwest-striking Zagros fold and thrust belt is an active continental collision zone that corresponds to a continental accretionary prism within the Arabian plate, which accommodates NNEtrending, between Arabia and Eurasia (Alavi, 1994; Talebian and Jackson, 2002; Tatar et al., 2002; Blanc et al., 2003; Regard et al., 2005).

Alborz and Talesh mountains surrounded western and southern border of the South Caspian Block (Fig. 1). The regular occurrence of large historical earthquakes in Alborz suggests an important deformation of this mountain belt in north of Tehran.

To the east, the east-striking Makran belt is the emerged portion of an accretionary prism resulting from the subduction of the Oman Gulf oceanic lithosphere beneath the Iranian Plate (Byrne et al., 1992; McCal, 1997; Kopp et al., 2000).

East of the South Caspian Block, and North of the active accretionary belts, Eurasian Plate is deformed in its interior up to $40^{\circ}$ north on the eaststriking Alborz and Kope-Dagh mountain belts (that accommodate part of the Arabia-Eurasia Convergence not absorbed by the Makran subduction) (Vernant et al., 2004, Regard et al., 2005; Zamani et al., 2008; Zamani, 2011). 


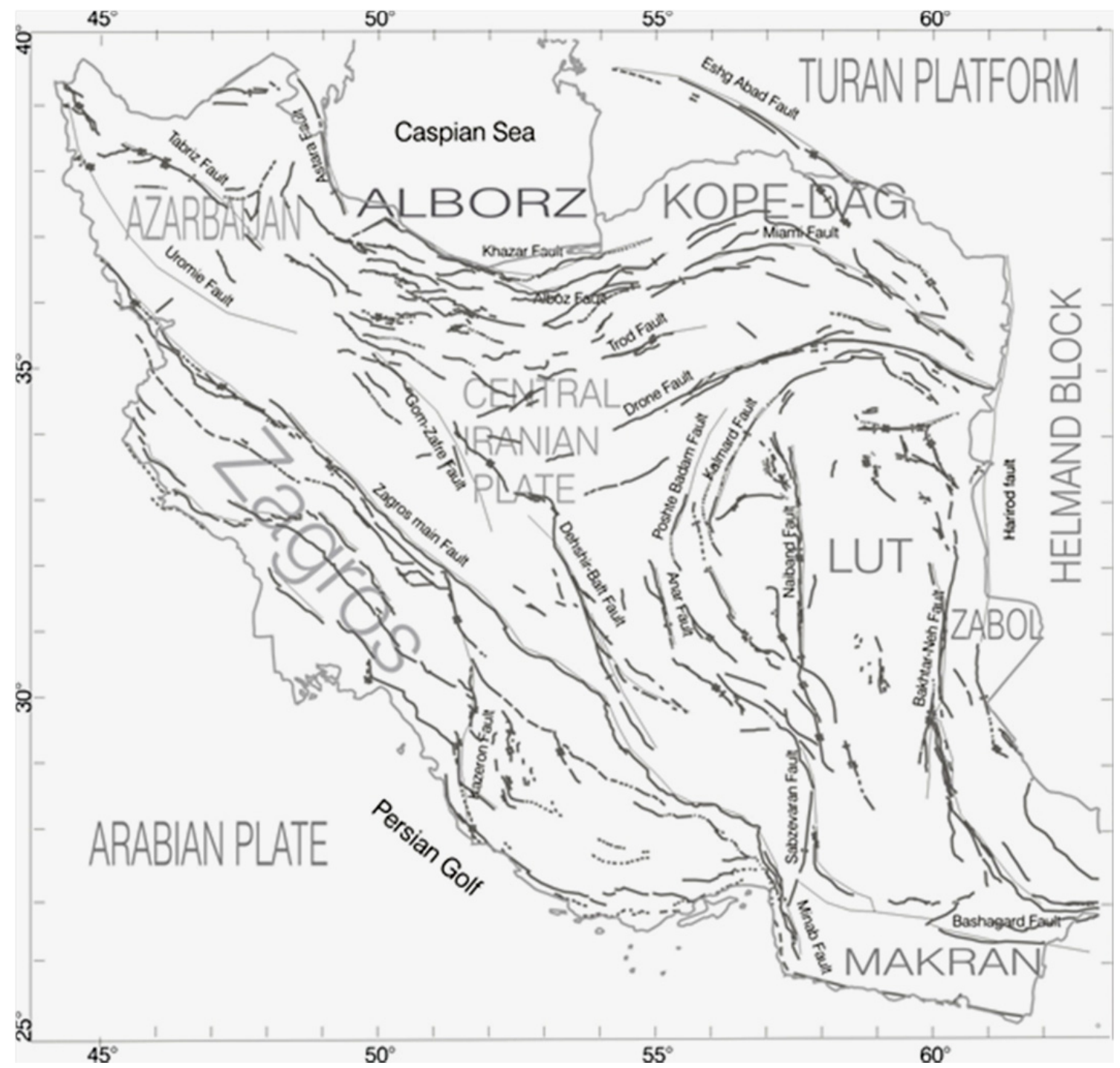

Fig. 1 Fault map and Tectonic setting of Iran.

Makran is a subduction structure and in the other mountain ranges of Iran collision is dominantly.

South of the Kope-Dagh belt, the Lut Block is bordered to the west and east by large strike slip faults (Conrad et al., 1982; Tirrul et al., 1983; Nowrozi and Mohajer-Ashjai, 1985; Walker and Jackson, 2002; Regard et al., 2005; Zamani et al., 2009).

Large strike slip motion is also reported along the Minab-Zendan-Palmi fault zone (Fig. 1) that corresponds to the transition zone between Zagros collision and Makran subduction (Haynes and McQuillan, 1974; Falcon, 1976; Regard et al., 2005). The deformation is accommodated between the two belts by two large-scale fault belts, namely the Nayband-Gowak and Neh-Zahedan north-trending fault systems, which separate the relatively undeformed Central Iran, Lut and Helmand blocks (Walker and Jackson, 2002; Regard et al., 2005).

\section{RESULTS OF STRESS ANALYSES AND DISPLACEMENT ANALYSIS IN IRAN}

To investigate the effect of the lateral heterogenties in the lithosphere on local and regional stress fields, in this research, tried to construct a twodimensional finite element model. For this purpose, three observation patterns were implemented as follows:

1. Results of GPS geodesy measurements in Iran

2. Stress orientations pattern

3. Stress ratio zoning

\subsection{SEISMIC DATA INVERSION AND DETERMIN- ING TECTONIC STRESS STATE OF IRAN}

In this study, the results of inversion of the focal mechanism solutions data from different resources used to study the state of stress in the crust of Iran. The Angelier inverse method (Angelier, 2002), adopted in this analysis, reveals the stress state that best accounts for a set of double couple focal mechanisms of earthquakes. In this method, the stress tensor is reduced to four unknowns; because, the sole consideration of shear stress orientations cannot give access to isotropic component and scale factor of stress (Angelier, 1984). 


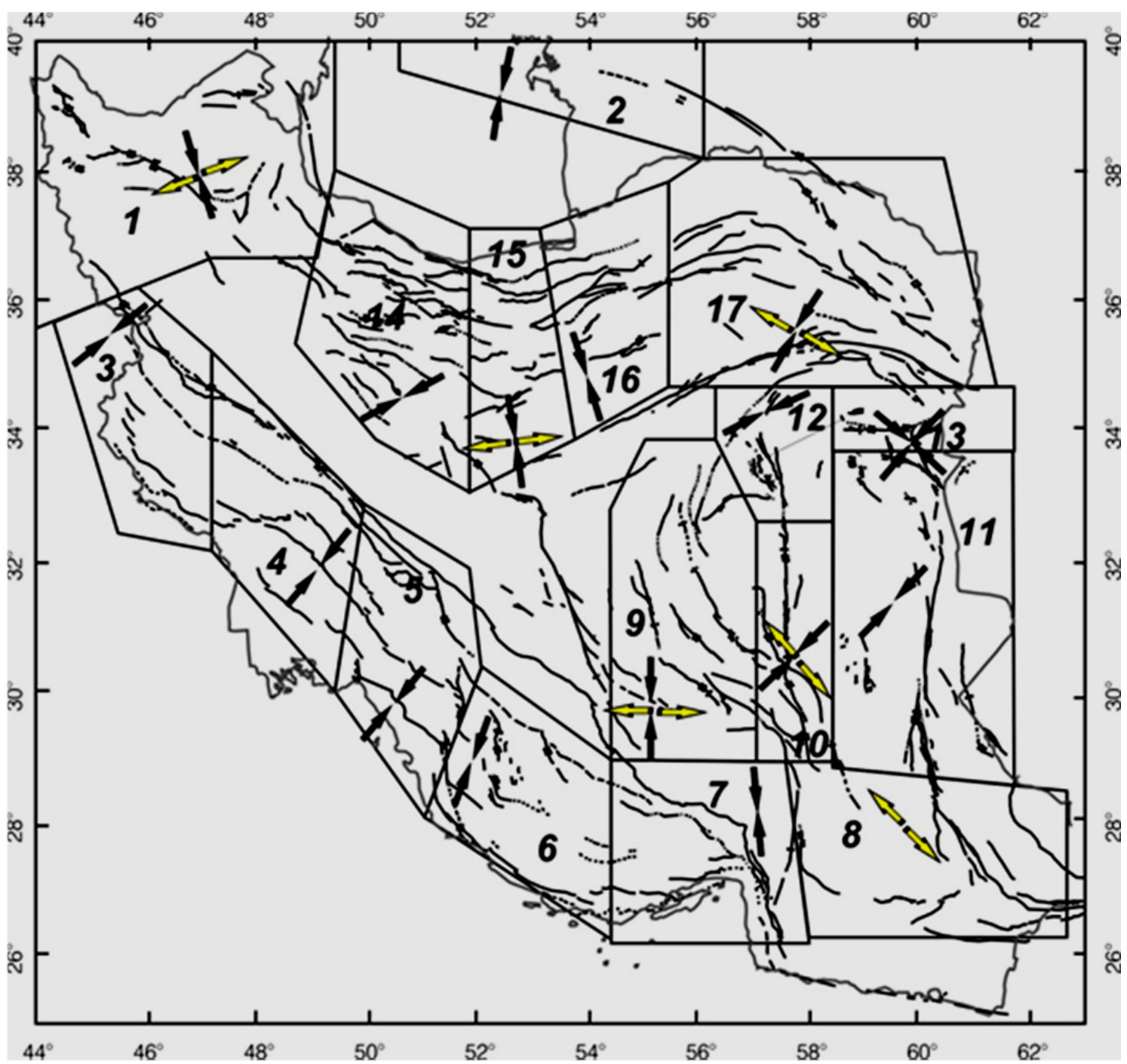

Fig. 2 Tectonic stress state of Iran (Zamani G., B., 2008) that is analyzed by method of Angelier (2002). a) stress trajectories of main compression in Iran. b) stress trajectories of deviated stress in Iran.

This method is based on the SSSC criterion (slip shear stress component). The SSSC is the component of stress acting in the slip direction of a fault. The intrinsic properties of the criterion adopted (SSSC) result in two main technical properties. First, no choice between the nodal planes is needed. Second, the numerical aspects are reduced to a minimum so that the runtime is negligible regardless of the size of the data set. Consequently, not only the large data sets could be processed, but also the SSSC-based inversion is easily included in a variety of processes to refine the data and to analyze the states of regional stress.

Results of this method revealed that the variation in magnitude and technical accuracy did not significantly influence the inversion. The selection of the data according to a preliminary delineation of seismogenic units resulted in more homogeneous data subsets (Angelier, 2002). Therefore, tectonic units of Iran are divided to the 17 seismotectonic provinces that each zone has different seismotectonic and structural properties. The relocated epicenters, role of $\mathrm{P}$ and $\mathrm{T}$ axes of focal mechanisms, together with geological information, structural trends, and active faults and base seismotectonic zoning of Iran (Nowrozi, 1976) are used to construct these seismotectonic provinces (Zamani, 2008).

The stress inversion of focal mechanisms implemented by the earthquakes recorded from 1931 to 2016 in Iran. A preliminary experiment involved the stress tensor determination between using each data subset as a whole. Then the stress inversion, which was done for each zone, obtained the final tectonic stress pattern (Zamani G., 2008) in zones (Fig. 2).

Zoback (1992) suggested that the interference of a regional stress field and superimposed uniaxial local stress field can be evaluated quantitatively and depends on the angle between the regional stress system $(\theta)$ and the local structures as well as on the relative magnitudes $(\varnothing)$ of the regional and local stress. The actual orientation of the intraplate stress field depends on the balance of forces acting on the plate and the plate geometry on which they act and can only accurately be predicted by detailed modeling such as finite element (Zoback, 1992). 


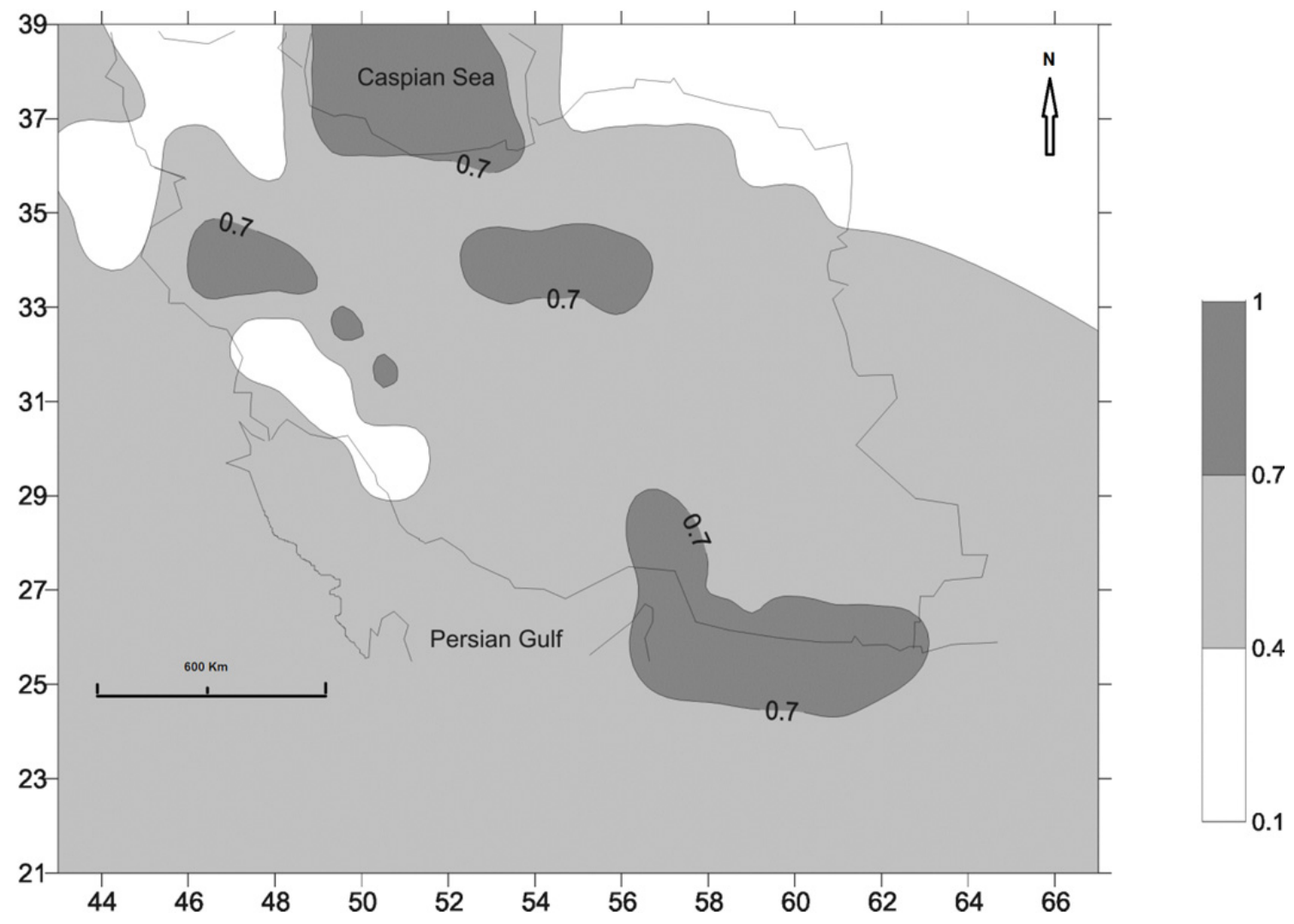

Fig. 3 Zoning of $\varnothing$ in Iran, which is shown $\varnothing$ is increased in Makran, Zagros, South Caspian and East of Central Iran.

Numerous finite element modeling studies have demonstrated that the knowledge of the first-order intraplate stress orientations and relative stress magnitudes (stress regimes) is a powerful factor in constraining force models. Because of the important role of these two parameters ( $\varnothing$ and $\theta$ values) in determining of first order intraplate stress orientations, the observation patterns for $\emptyset$ value (Fig. 3 relative stress magnitudes pattern) and $\theta$ value (Fig. 2) are made, for comparing with FEM model results.

\subsection{DISPLACEMENT ANALYSIS BY GEODETIC RESULTS}

A GPS network of 28 sites was installed and surveyed twice in September 1999 and October 2001 by Iranian and French research organizations (Nilforoushan et al., 2003; Vernant et al., 2004; Masson et al., 2005, 2006). The distribution of the mentioned sites (Masson, et al., 2006) fits by seismotectonic zoning blocks of Iran, used in this study. This GPS network has reduced velocities and movement orientations of each part.

The results of the geodetic data show the ArabiaEurasia convergence is accommodated differently in eastern and western Iran. East of $58^{\circ}$, most of the shortening is accommodated by the Makran subduction zone $\left(19.5 \pm 2 \mathrm{mmyr}^{-1}\right)$ and less by the Kope-Dagh $\left(6.5 \pm 2 \mathrm{mmyr}^{-1}\right)$. West of $58^{\circ} \mathrm{E}$, the longitude of Tehran, the Zagros and the Alborz mountain ranges accommodate $6.5 \pm 2 \mathrm{mmyr}^{-1}$ and $8 \pm 2 \mathrm{mmyr}^{-1}$ respectively. The right-lateral displacement along the main recent fault in the northern Zagros is about $3 \pm 2$ mmyr $^{-1}$ smaller than what was generally expected. The central Iran block is characterized by coherent plate motion (internal deformation $<2 \mathrm{mmyr}^{-1}$ ). The sites east of $61^{\circ} \mathrm{E}$ show very low displacement relative to Eurasia. Strike slip motions along the Lut block accommodate the kinematics contrast between eastern and western Iran. To the south, the transition zone between Zagros and Makran is under transpression with right-lateral displacements of $11 \pm 2$ mmyr $^{-1}$ (Vernant et al., 2004; Regard et al., 2005). The GPS geodesy measurements reduced the displacements in crust of Iran and their results are used in FEM modeling of Iran. Initial horizontal displacements applied in the different possible directions of the plate motion relative to Eurasia, in this modeling.

In Figure 4 GPS velocity, patterns are shown (fitted by seismotectonic provinces of Iran) that the velocities are reduced from the South to the North and also from the West to the East.

\section{NUMERICAL MODELING}

\subsection{THE FINITE ELEMENT METHOD}

In this paper, the finite element method (FEM) is used to evaluate the stress field associated with the tectonic forces in Iran. Numerical modeling by the finite element method can be classified to two types: forward and inverse analyses. The former calculates the stress orientations, in the continent from known tectonic forces and rheological parameters. The latter estimates some unknown forces and rheological parameters from observations (e.g. orientations) and some known tectonic forces and rheological parameters. In this paper, the inverse modeling 

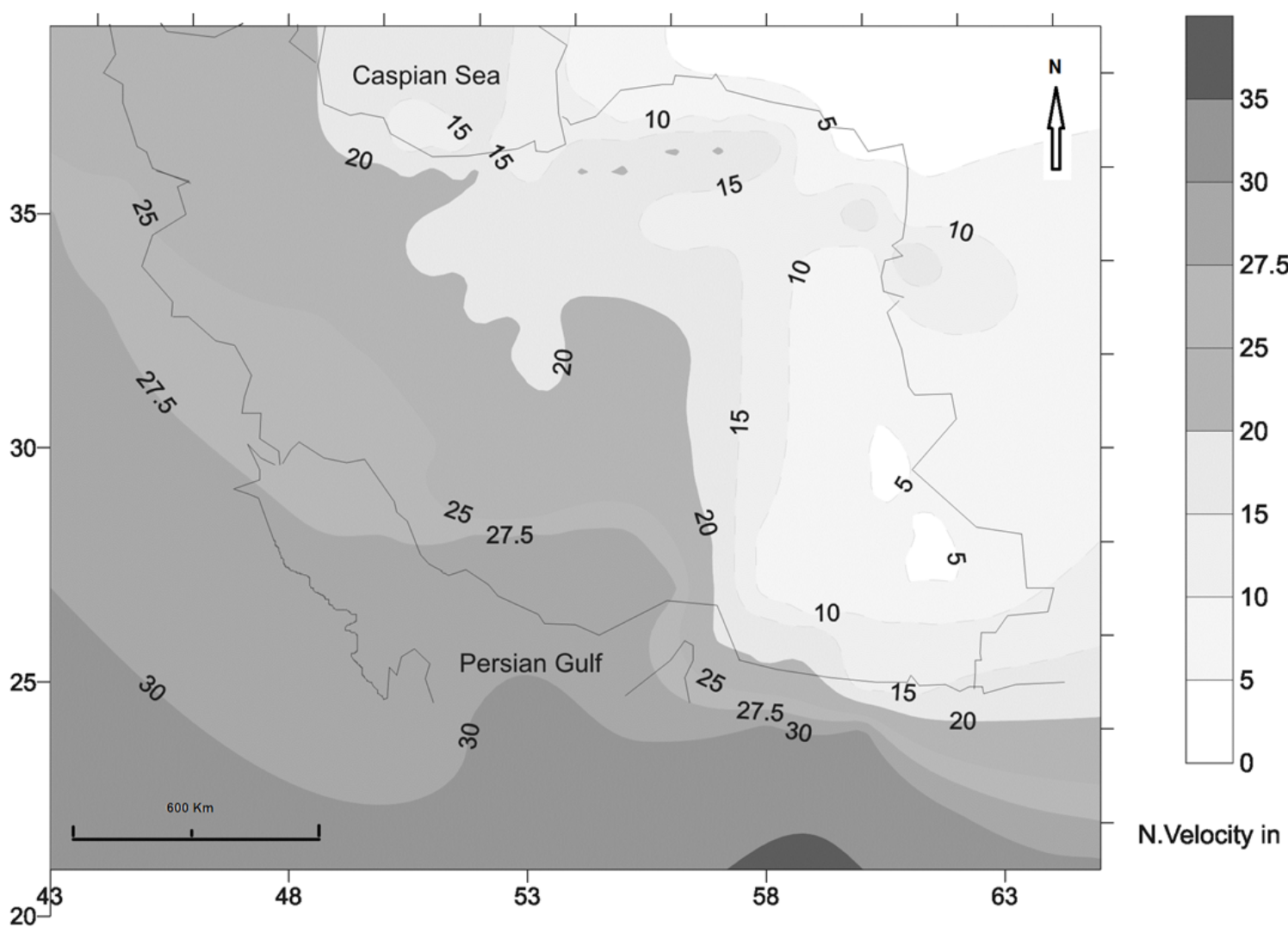

N.Velocity in $\mathrm{mm} / \mathrm{yr}$
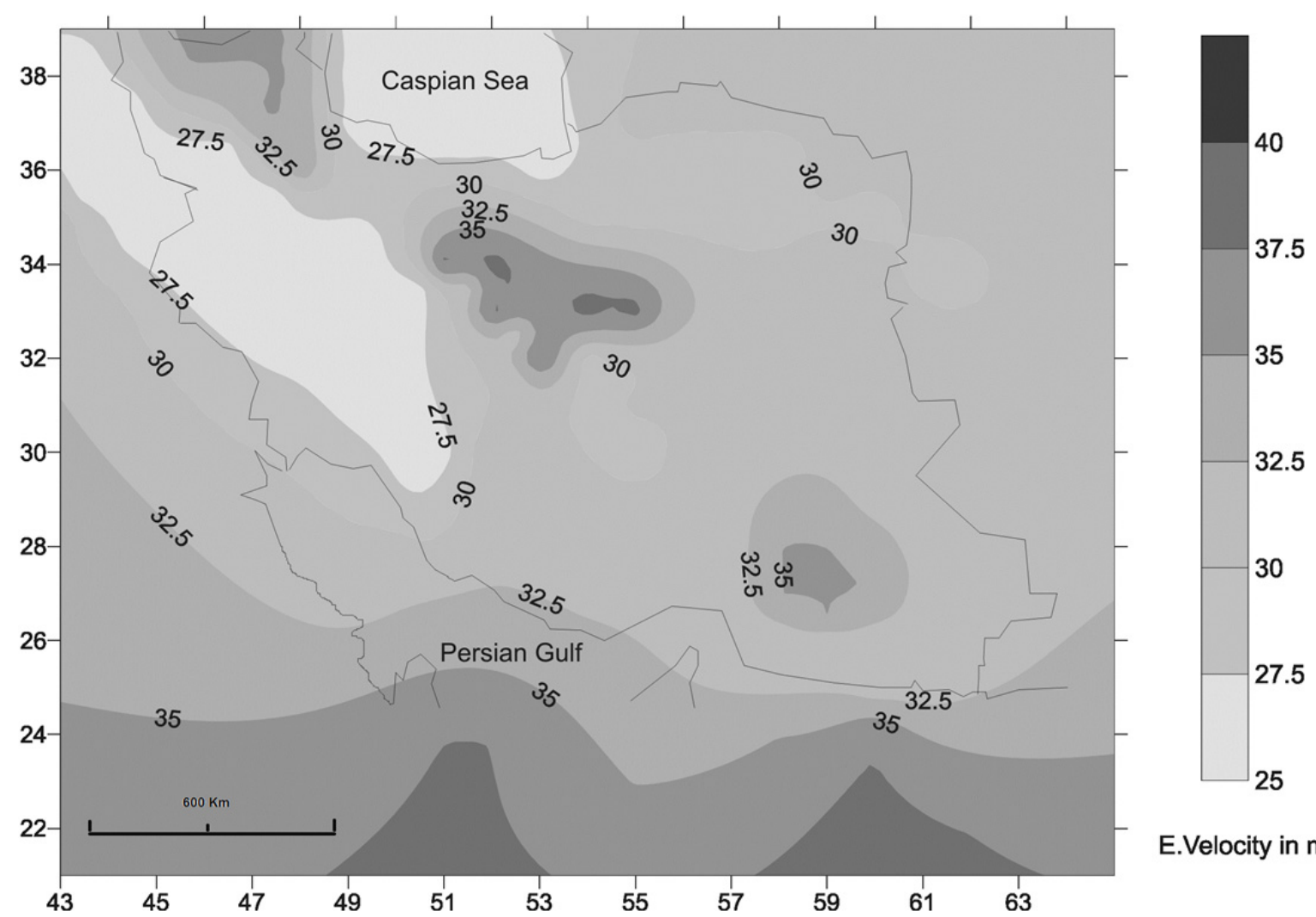

E.Velocity in $\mathrm{mm} / \mathrm{yr}$

Fig. 4 GPS velocity zoning in Iran,

a) GPS N-velocity (in mm/yr), which is shown, velocities are reduced from South and West to the North and East of Iran. b) GPS E-velocity (in mm/yr), which is shown, velocities are reduced from South and West to the North and East of Iran. 
technique is used to estimate the rheological parameters of the major blocks in Iran by stress orientations, several relative magnitudes and geodetic data. For the details of the formulations of the FEM and related topics, the reader is referred to the available literature (e.g. Zienkiewicz and Taylor, 1998).

\subsection{MODEL ASSUMPTIONS AND ANALYSES}

In this study, a two-dimensional elastic plain stress model is used to simulate the response of the Iranian continent to various tectonic forces. It would be an oversimplification to use elastic rheology in the stress analyses for the Iranian continent, and using it for modeling the evolution of the stress in the continent through time is not possible. An alternative, such as a viscoelastic rheology, may be more suitable for investigating the stress relaxation process in the crust/lithosphere (Stephenson and Lambeck, 1985). However, a three-dimensional, continental scale modeling with a viscoelastic rheology for the Iranian continent is still difficult, since the changes of tectonic forces over time in the continent are not well known and, furthermore, there are no sufficient observations and enough data to constrain such models. Therefore, an elastic rheology is a reasonable approach for investigating and modeling the first order tectonic stress in Iran. The finite element model used in this study has a 2-dimensional grid that the error in delineating the boundaries of tectonic blocks is up to $\sim 50 \mathrm{~km}$. Therefore, only the tectonic blocks wider than $100 \mathrm{~km}$ are taken into account in the analyses whereas small structures, e.g. local faults (usually less than $100 \mathrm{~km}$ in width), are ignored in our continental scale model.

In this study, in situ stress has calculated by normalizing the vertical stress at earthquake depths in zones. The magnitudes of horizontal stress for zones are estimated by suggested equations by Brace and Kohlested (1980) and replacing Ø.

Dehgani and Markis (1983) suggested that the mean crustal density in Iran is 2.75 (density of mountains, mountain-roots and upper mantle respectively is $2.67,2.85$ and 2.85). The difference of these density values (and Young's modulus that is described below) represents the unisotropy and differences of the geological elements in their elastic strength associated with density and rigidity.

Therefore there is a two-dimensional model that includes a variety of sub domains (17 seismotectonic provinces) with different material properties, in order to represent the mechanical behavior of seismotectonic provinces in Iran. The model parameters including the elastic properties of various blocks, that best fit model parameters is shown in Table 1.

Numerous experiments were done with different boundary conditions and rheology. Model calculations as suggested Grünthal and Stromeyer (1992) were carried out with different degrees of decreased Young's modulus for the plastic regions and with different degrees of increased Young's modulus for
Table 1 Model parameters properties used in the model.

\begin{tabular}{cc}
\hline $\begin{array}{c}\text { Young's modulus } \\
\text { (Gpa) }\end{array}$ & Poisson's ratio \\
\hline $10-100$ & 0.3 \\
\hline
\end{tabular}

the rigid regions. Different combinations of Young's modulus are examined and adjusted to fit the observed patterns.

In this study, the main objective by inverse analyses is to estimate the Young's modulus. Our tests indicate that variation of the Young's modulus from 1 to 10 Gpa (Turcotte and Schubert, 2002) does not make an optimum model. Adopting the variation of the Young's modulus from 10 to $100 \mathrm{Gpa}$ (Turcotte and Schubert, 2002) have made a true model that is comparable with the tectonic of Iran.

In this model a constant value 0.3 was adopted for the Poisson's ratio throughout the investigated area. Boundary conditions include, velocities and displacements, whereas the velocity of plate movements between the Arabian plate, Iranian microplate and Eurasian plate is well known. The northeast corner of the model is fixed, under this condition; displacement is left free along $\mathrm{E}-\mathrm{W}$ direction for the northern boundary and along the N-S direction for the northeastern boundary. In fact this is similar to those occurring near the plate boundaries, in agreement with the geological observations. Also different displacements as functions of latitudes and longitudes along the other boundaries apply with respect to the GPS geodetic data displacements.

These procedures were repeated until the fitting between the observed and modeled patterns reached the minimum difference and the final model was generated (Fig. 5).

\section{RESULTS AND CONCLUSIONS}

The models presented herein and used to calculate the stress distribution have been drastically simplified with respect to the actual structures and tectonics near plats. However, they provide a rigorous framework for interpreting the stress distribution observed (Fig. 2) in relation to the major features and kinematics of Iran plateau (Figs. 5, 6).

The modeled stress field for Iran shown in Figure 5 denotes that the maximum stress is dominantly in NW of Zagros (collision head), Azarbaijan, Kope-Dagh provinces, Qatar- Kazeron fault zone, and Zabol and Lut blocks.

These results are mainly in agreement with the considerations of stress inversion that is shown in Figure 3 (stress ratio zoning). But in some parts, the Phi ratio zoning and simulation results are not consistent with the actual condition. Note that the FEM model, geodetic determinations of the plate convergence direction (Vernant et al., 2004) and direction of seismotectonic compression in the same region were completely independent and could be a little different. However, they are mainly converging and, therefore, the results of these three methods can be used to support each other. In addition, the 


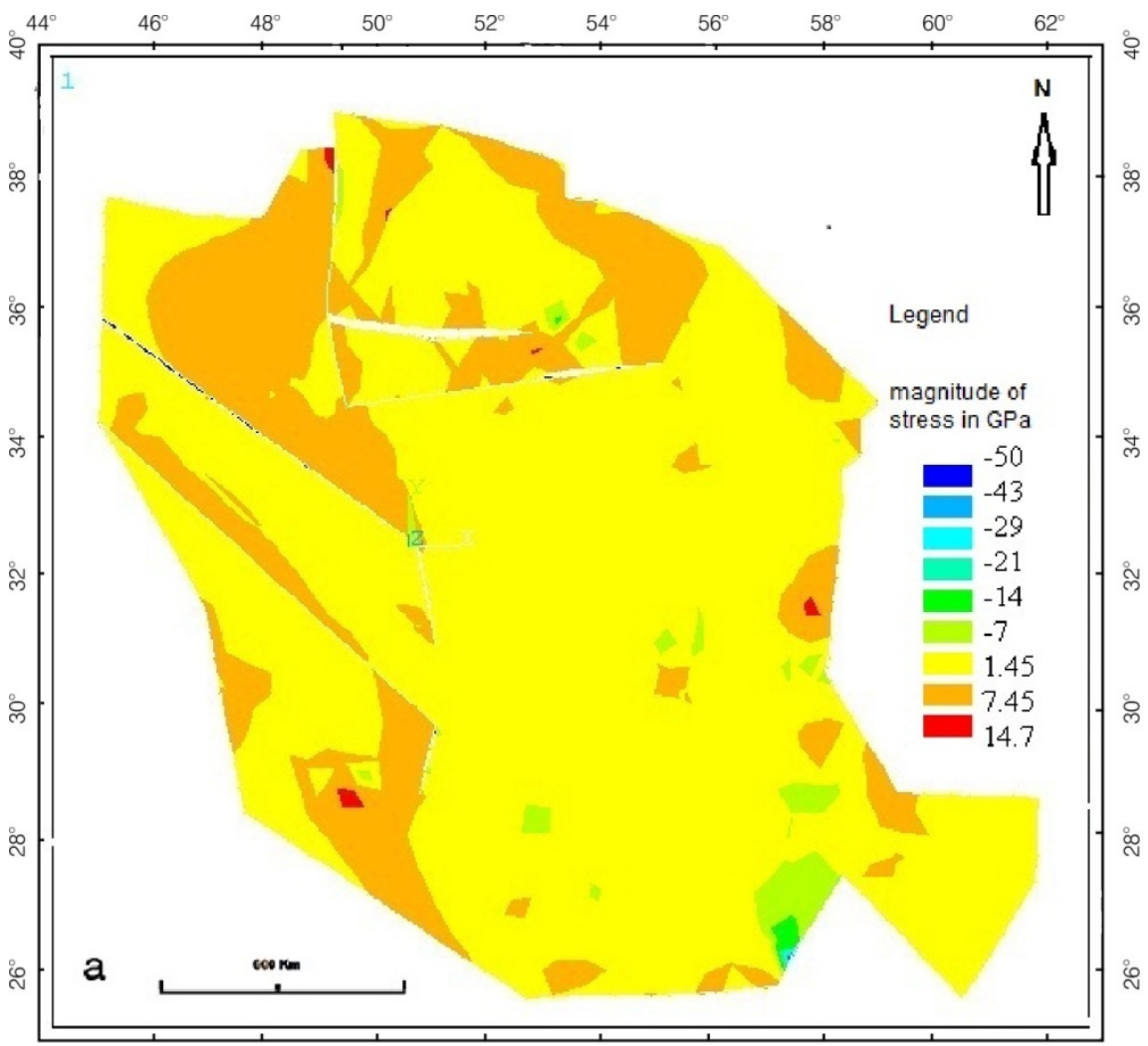

Fig. 5a FEM 2D Elastic stress models of Iran,

Stress (FEM) model that is made by analyses in N-S direction and it is shown maximum stress is dominantly in Zagros, Azarbaijan, Kope-Dag and Qatar-Kazeron fault area.

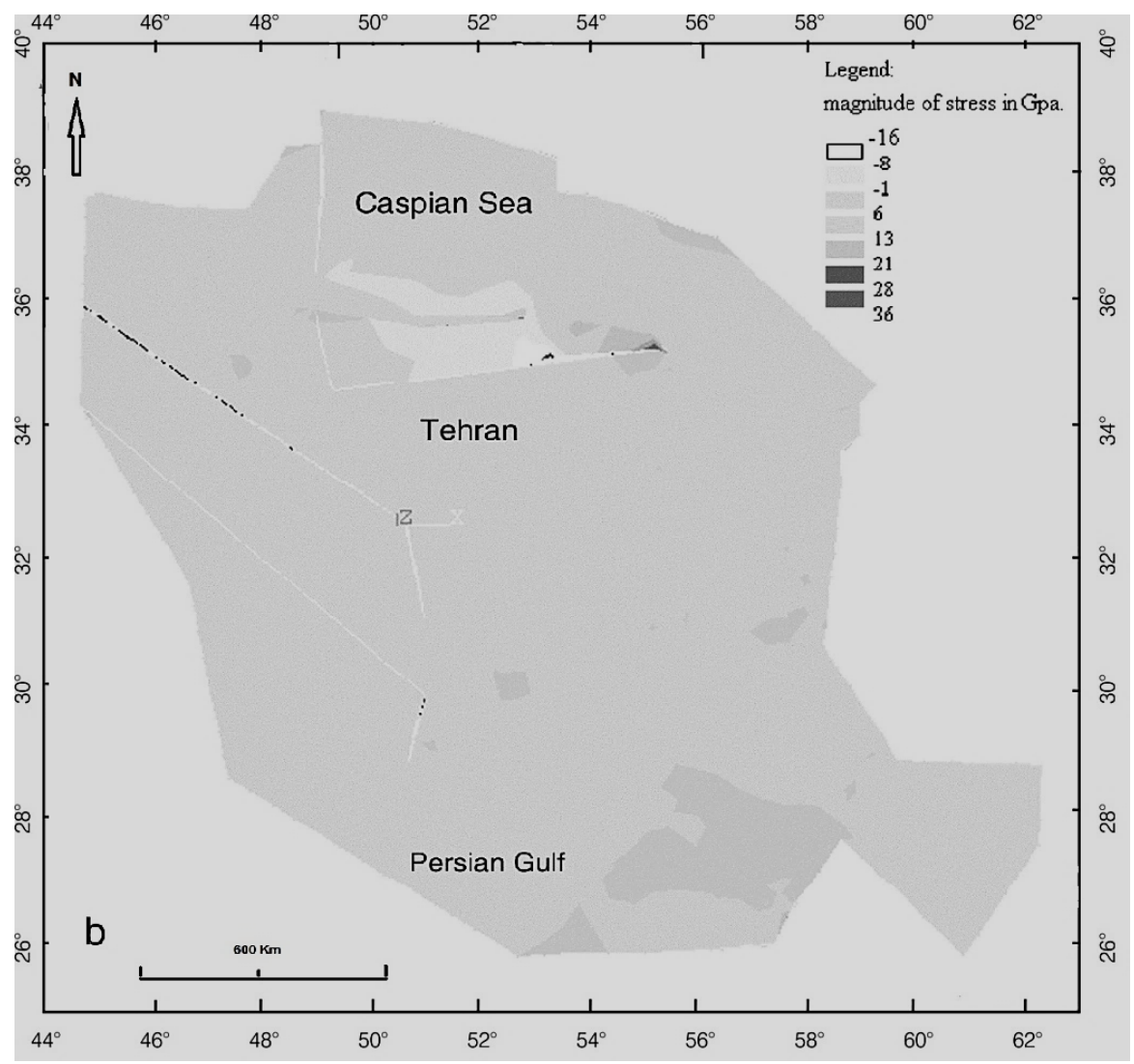

Fig. 5b FEM 2D Elastic stress models of Iran,

Stress (FEM) model that is made by analyses in E-W direction. 


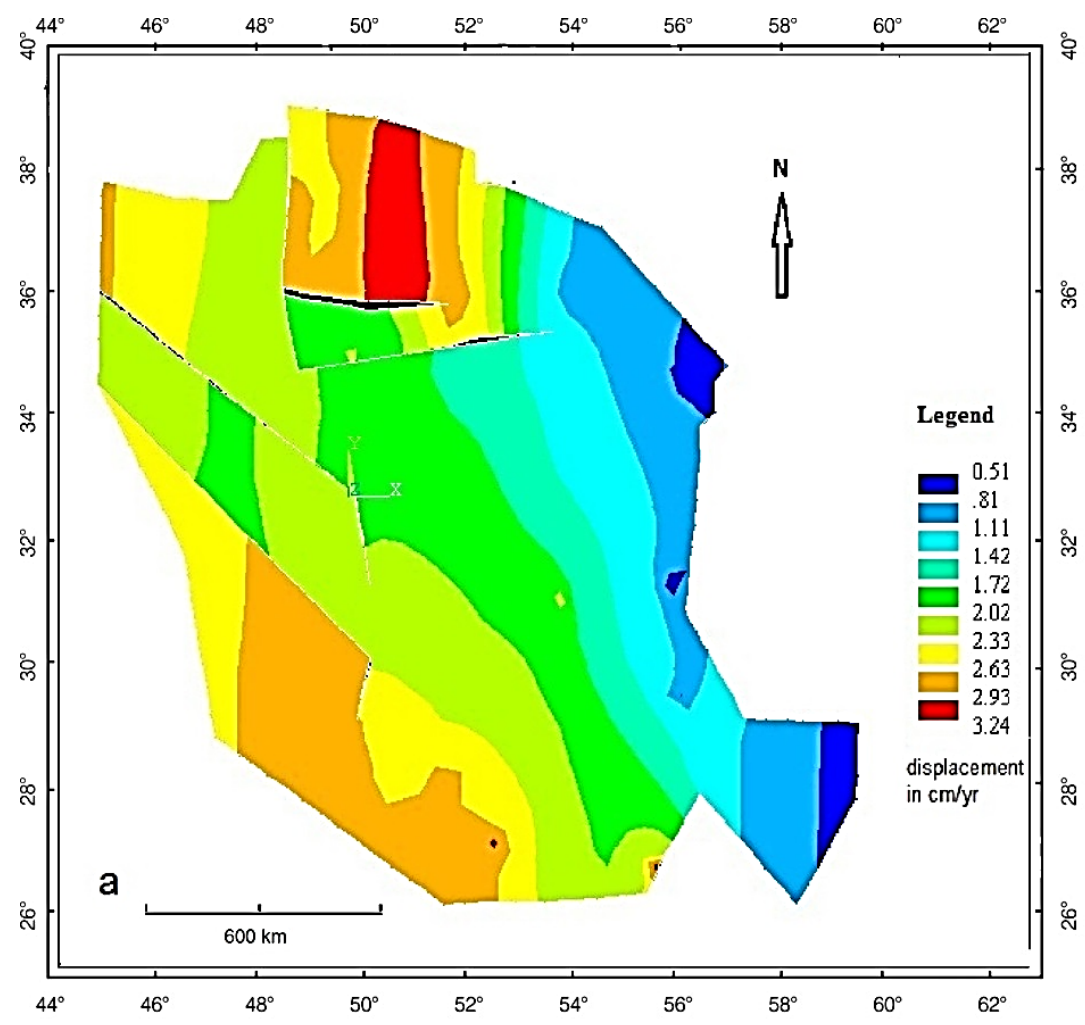

Fig. 6a FEM 2D models of tectonical displacements in Iran,

Displacement(FEM) model in N-S direction which is shown displacements are reduced from South to North and West to East of Iran.

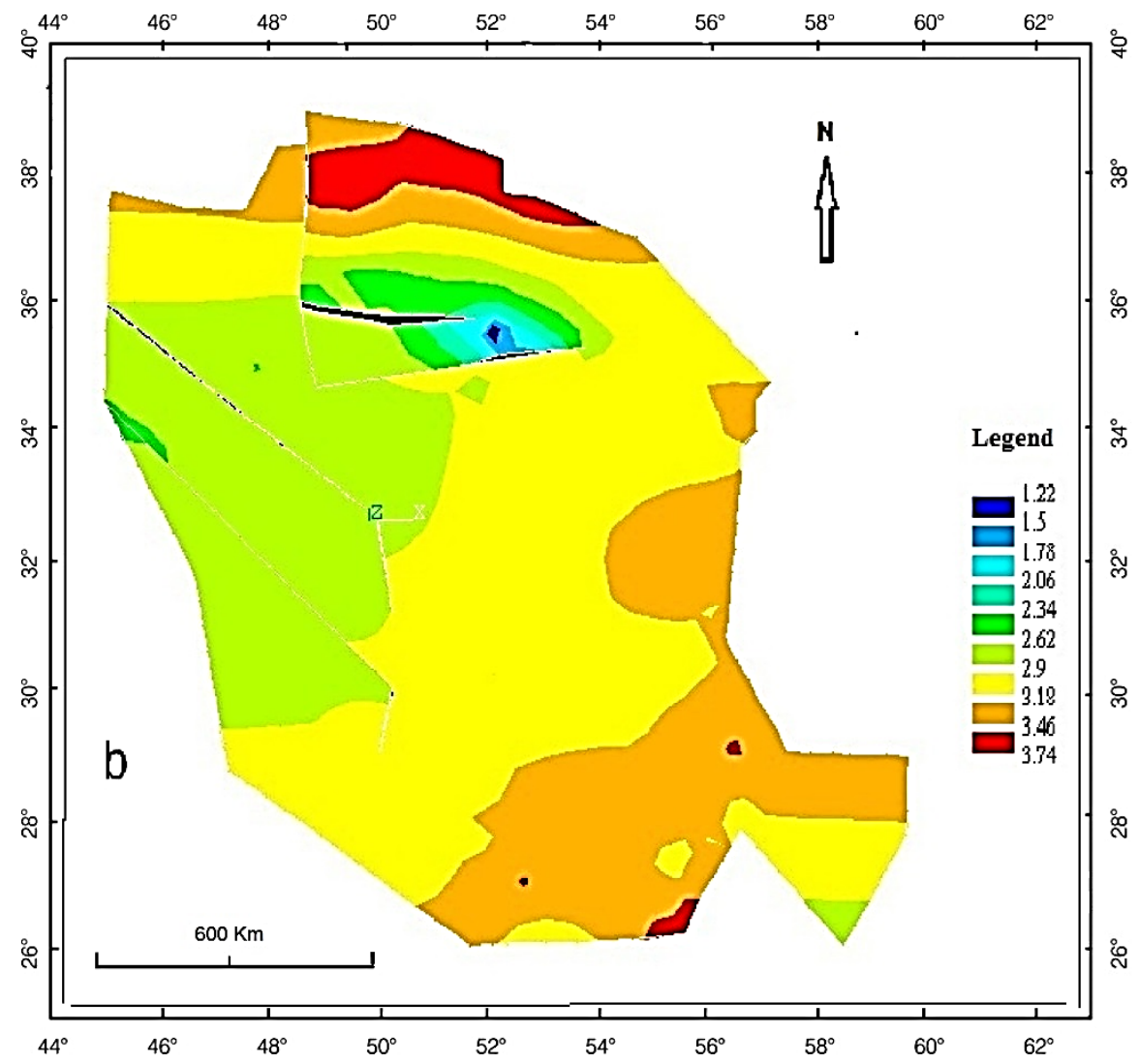

Fig. 6b FEM 2D models of tectonical displacements in Iran,

Displacement (FEM) model in E-W direction which is shown displacements are reduced in Zagros and are increased from South to North and West to East of Iran. 
geodetic data indicated the displacements on the surface of upper crust, but the seismic data may also apply to the deeper underlying faults, which could denote in different results.

Figure 6 shows the displacements model of Iran (the displacements in north-south and east-west direction respectively). The resultant pattern (Fig. 6) is very similar to the GPS velocity field in N-S direction (Fig. 4), in both of which the displacements decrease to the eastward. The results of this modeling show that the Iran-Arabia collision, in Zagros (in the west), the Turan platform at the north and the Helmand block at east are the major constrictions of the block displacements. Furthermore, the results show that the magnitude of the maximum principal stress axes $(\delta 1)$ decrease from west and southwest to the north and northeast of Iran. Furthermore, the plunge of $\delta_{2}$ has changed to vertial from west to the east and central Iran. In Anderson's law, this is the reason of change from thrusting to the strike slip mode of fault movements from west to east and central Iran and related earthquakes (such as Dorone, Poshte-Badam, Nain faults and the other blind faults in crust - Fig. 1).

Based on previous experiments, I conclude that the distribution of stress trajectories in the Iranian plate is mainly controlled by:

1. Geometric configuration of the boundary between Arabian plate, Eurasia and Iran,

2. Shape and reological properties of the major structural units,

3. Direction of convergence of the Arabian plate relative Eurasia,

4. Influence of the subduction of Makran

I could say the study of two-dimensional elastic finite-element modeling of Iran allows, estimating the influence of different parameters in the stress pattern. This model shows that the direction of convergence and shape of the plate boundary play a significant role, and, are the main factors controlling the shape of the distribuion of the maximum compressional stress.

Better constrained attempts and 3D-viscoelastic modeling studies, in corporation with depth-dependent features, have to be developed to describe the rheological structure of the lithosphere in Iran.

\section{ACKNOWLEDGMENTS}

The University of Tabriz and the Ministry of the Sciences, Research and Technology of Iran supported this study. I dedicate this research to Prof. Jacques Angelier (deceased).

\section{REFERENCES}

Alavi, M.: 1994, Tectonic of the Zagros orogenic belt of Iran: New data and interpretations. Tectonophysics, 229, 3, 211-238. DOI: 10.1016/0040-1951(94)90030-2

Ambraseys, N.N. and Melville, C.P.: 1982, A History of Persian Earthquakes, Cambridge University Press, New York.
Angelier, J.: 1984, Tectonic analysis of fault slip data sets. J. Geophys. Res., 89, B7, 5835-5848. DOI: 10.1029/JB089iB07p05835

Angelier, J.: 2002, Inversion of earthquake focal mechanisms to obtain the seismotectonic stress IV - a new method free of choice among nodal planes. Geophys. J. Int., 150, 3, 588-609. DOI: 10.1046/j.1365-246X.2002.01713.x

Blanc, E.J.-P., Allen, M.B., Inger, S. and Hassani, H.: 2003, Structural styles in the Zagros simple folded zone. Iran. J. Geol. Soc. Lond., 160, 401-412.

Brace, W.F. and Kohlestedt, D.L.: 1980, Limits on lithospheric stress imposed by laboratory experiments. J. Geophys. Res., 85, B11, 6248-6252. DOI: $10.1029 / J B 085 i B 11 \mathrm{p} 06248$

Byrne, D.E., Sykes, L.R. and Davis, D.M.: 1992, Great thrust earthquake and aseismic slip along the boundary of the Makran subduction zone. J. Geophys. Res., 97, B1, 449-478. DOI: 10.1029/91JB02165

Conrad, G., Montigny, R., Thuizat, R. and Westphal, M.: 1982, Dynamique cénozoique du bloc du Lout (Iran) d'après les données paleomagnétiques, isotopiques, petrologiques et structurales. Géol. Médierranéenne, 9, $1,23-32$.

Dehgani, G.A. and Makris, J.: 1983, The gravity field and crustal structure of Iran. Geol. Surv. Iran, 51, 51-68.

Engdahl, E.R., van der Hilst, R. and Buland, R.: 1998, Global teleseismic earthquake relocation with improved travel times and procedures for depth determination. Bull. Seism. Soc. Am., 88, 3, 722-743.

Falcon, N.L.: 1976, The Minab anticline: the geological evolution of Southern Iran: the report of the Iranian Makran expedition. Geograph. J., 142, 409-410.

Grünthal, G. and Stromeyer, D.: 1992, The recent crustal stress field in central Europe: Trajectories and finiteelement modeling. J. Geophys. Res., 97, B8, 1180511820. DOI: $10.1029 / 91 J B 01963$

Haynes, S.J. and McQuillan, H.: 1974, Evolution of the Zagros suture zone, southern Iran. Geol. Soc. Am. Bull., 85, 739-744.

Jackson, J.A. and McKenzie, D.P.: 1984, Active tectonics of the Alpine-Himalayan Belt between western Turkey and Pakistan. Geophys. J. Int., 77, 185-264. DOI: $10.1111 / j .1365-246 X .1984 . t b 01931 . x$

Jackson, J.A. and McKenzie, D.: 1988, The relationship between plate motions and seismic moment tensors, and the rates of active deformation in the Mediteranean and Middle East. Geophys. J. Int., 93, 1, 45-73. DOI: 10.1111/j.1365-246X.1988.tb01387.x

Kopp, C., Fruehn, J., Flueh, E.R, Reichert, C., Kukowski, N., Bialas, J. and Klaeschen, D.: 2000, Structure of the Makran subduction zone from wide angle and reflection seismic data. Tectonophysics, 329, 1, 171191. DOI: $10.1016 / \mathrm{S} 0040-1951(00) 00195-5$

Masson, F., Chery, J., Hatzfeld, D., Martinod, J., Vernant, P., Tavakoli, F. and Ghafory-Ashtiani, M.: 2005, Seismic versus aseismic deformation in Iran inferred from earthquakes and geodetic data. Geophys. J. Int., $160,1,217-226$. DOI: $10.1111 / \mathrm{j} .1365-246 X .2004 .02465 . \mathrm{x}$

Masson, F., Van Gorp, S., Chéry, J., Djamour, Y., Tatar, M., Tavakoli, F., Nankali, H. and Vernant, P.: 2006, Extension in NW Iran driven by the motion of the South Caspian Basin. Earth Planet. Sci. Lett., 252, 1, 180-188. DOI: 10.1016/j.eps1.2006.09.038 
McCall, G.J.H.: 1997, The geotectonic history of the Makran and adjusent areas of southern Iran. J. Asian Earth Sci., 15, 6, 517-531.

Nilforoushan, F., Masson, F., Vermant, P., Vigny, C., Martinod, J., Abbasi, M., Nankali, H., Hatzfeld, D., Bayer, R.,Tavakoli, F., Ashtiani, A., Doerflinger, E., Daignieres, M., Collard, P. and Chery, J.: 2003, GPS network monitors the Arabia-Eurasia collision deformation in Iran. J. Geod., 77, 7, 411-422. DOI 10.1007/s00190-003-0326-5

Nowrozi, A.A.:1976, Seismotectonic provinces of Iran. Bull. Seism. Soc. Am., 66, 4, 1249-1276.

Nowroozi, A.A. and Mohajer-Ashjai, A.: 1985, Fault movements and tectonics of the eastern Iran: boundaries of the Lut plate. Geophys. J. Int., 83, 1, 215-237. DOI: 10.1111/j.1365-246X.1985.tb05164.x

Regard, V., Bellier, O., Thomas, J.-C., Bourles, S., Bonnet, M. R., Abbassi, R., Mercier, J., Shabanian, E., Soleymani, Sh. and Feghhi, Kh.: 2005, Cumulative right-lateral fault slip rate across the Zagros-Makran transfer zone: role of the Minab-Zendan fault system in accommodating Arabia-Eurasia convergence in southeastern Iran. Geophys. J. Int., 162, 1, 177-203. DOI: $10.1111 /$ j.1365-246X.2005.02558.x

Stephenson, R. and Lambeck, K.: 1985, Isostatic response of the lithosphere with in-plane stress: Application to central Australia. J. Geophys. Res., 90, B10, 85818588. DOI: $10.1029 / \mathrm{JB} 090 \mathrm{iB} 10 \mathrm{p} 08581$

Talebian, M. and Jackson, J.A.: 2002, Offset on the main recent fault of NW Iran and implications for the late Cenozoic tectonics of the Arabia-Eurasia collision zone. Geophys. J. Int., 150, 2, 422-439. DOI: 10.1046/j.1365-246X.2002.01711.x

Tatar, M., Hatzfeld, D., Martinod, J., Walpersdorf, A., Ghafori-Ashtiany, M. and Chery, J.: 2002, The present-day deformation of the central Zagros from GPS measurements. Geophys. Res. Lett., 29, 19, 331334. DOI: $10.1029 / 2002$ GL 015427

Tirrul, R., Bell, I.R., Griffith, R.J. and Camp, V.E.: 1983, The Sistan suture zone of eastern Iran. Geol. Soc. Am. Bull., 94, 134-150.

Turcotte, D. and Schubert, J.: 2002, Geodynamics, Cambridge University Press, 456 pp.
Vernant, Ph., Nilforoushan, F., Hatzfeld, D., Abbasi, M.R., Vigny, C., Masson, F., Nankali, H., Martinod, J., Ashtiani, A., Tavakoli, F. and Chery, J., 2004. Present-day crustal deformation and plate kinematics in the Middle East constrained by GPS measurements in Iran and northern Oman. Geophys. J. Int., 157, 381398. DOI: $10.1111 /$ j.1365-246X.2004.02222.x

Walker, R. and Jackson, J.A.: 2002, Offset and evolution of the Gowk fault, S.E. Iran: a major intra-continental strike-slip system. J. Struct. Geol., 24, I677-1698.

Zamani, G. Behzad: 2008, Study of tectonic stress state of Iran. Ph.D. thesis, Shiraz University, Iran.

Zamani, G. Behzad: 2011, State of stress in the northern Tabas block, east-central Iran, as inferred from focal mechanisms of the 1978 Tabas earthquake sequence. Central European Journal of Geosciences, 3, 1, 77-89. DOI: $10.2478 / \mathrm{s} 13533-011-0011-9$

Zamani, G. Behzad, Angelier, J. and Zamani, A.: 2008, State of stress induced by plate convergence and stress partitioning in northeastern Iran, as indicated by focal mechanisms of earthquakes. J. Geodyn., 45, 120-132. DOI: $10.1016 /$ j.tecto.2013.10.015

Zamani, G., Behzad and Masson, F.: 2014, Recent tectonics of East (Iranian) Azarbaijan from stress state reconstruction. Tectonophysics, 611, 61-82. DOI: $10.1016 /$ j.tecto.2013.10.015

Zienkeiwicz, O.C. and Taylor, R.L.: 1988, The Finite Element Method, Vol. 1, Basic formulation and linear problems. McGraw-Hill Bock Co., London, Fourth Edition, 648 pp.

Zoback, M.L.: 1992, First- and second-oder patterns of stress in the lithosphere: The World Stress Map Project. J. Geophys. Res., 97, B8, 11703-11728. DOI: $10.1029 / 92 J B 00132$ 